\title{
Investigation and analysis on the current situation of English translation of the three Kingdoms Cultural attractions in Jingchu Area, China
}

\author{
Jingwen Chen, Yan Fang Hou
}

School of Foreign Studies, Yangtze University, Hubei, 424023 PRC China

Received: 09 Sept 2020; Received in revised form: 13 Nov 2020; Accepted: 23 Nov 2020; Available online: 07 Dec 2020 (C)2020 The Author(s). Published by Infogain Publication. This is an open access article under the CC BY license (https://creativecommons.org/licenses/by/4.0/).

\begin{abstract}
With the increasing promotion of reform and opening-up as well as the globalization, there are an ever-increasing number of tourists coming to China for sightseeing. And the rapid development of tourism industry makes a further study for scenic spots translation become a must.In all Chinese places and regions, the Jingchuarea, mainly covering Hubei, Hunan and Sichuan province in China, is an important cradle of Three Kingdoms Culture. However, the quality of translation in related spots is uneven and many translation problems are not rare. This research, guided by the Skopostheorie and communicative translation, probes deeply into the current translation situation and translation problems of the Three Kingdoms Cultural Attractions in Jingchu area in China. Then, based on the investigation, the influential factors in translation are analyzed and some strategies to improve translation are given in order to modify the translated versions and promote the cultural communication.
\end{abstract}

Keywords- translation of scenic spots; Three Kingdoms Culture; skopostheorie; communicative translation.

\section{INTRODUCTION}

The brilliant and unique Chinese civilization has attracted numerous overseas tourists every year who plan to experience its cultural characteristics. In China, "Three Kingdoms Culture" is a unique cultural phenomenon, which has a broad and profound effect upon Chinese people's cultural life. Three Kingdoms Period(220-280) refers to the time between the late Eastern Han Dynasty and Jin Dynasty. And the Three Kingdoms Culture in Jingchu area mainly refers to the summation of the material wealth and spiritual wealth created by Chu people or Jingchu community in the process of social and historical development based on the historical facts of the Three Kingdoms and relevant historical culture.

As one of the important cradles of culture of Three Kingdoms, Jingchu area (mainly covers Hubei, Hunan and Sichuan province in China) has affluent tourism resources. However, at present, a lot of problems exist in the translation of scenic spots of Three Kingdoms in Jingchu area. So it is of great significance to modify the translation in the relevant scenic spots and improve the international image.

From the perspective of skopostheorie and 
communicative translation, this research analyzes the current translation situation and translation problems of the Three Kingdoms Cultural Attractions in Jingchuarea in China. After completing analysis, influential factors and some translation strategies are explored for the modified versions and cultural exchanges around the world.

\section{THEORETICAL FRAMEWORK AND RESEARCH METHODS}

\subsection{Theories for This Study}

\subsubsection{Peter Newmark's Communicative Translation}

Peter Newmark (1981), a famous British translation theorist, put forward two methods of translation, namely communicative translation and semantic translation. Communicative translation focuses mainly on the understanding and response of the target language readers and attempts to produce on its readers an effect as close as possible to that obtained on the readers of the original. In other words, as Shuttleworth and Cowie (1997:21) claimed, communicative is generally oriented towards the needs of the target language reader or recipient. A translator who is translating communicatively will treat source text as a message rather than a mere string of linguistic units, and will be concerned to preserve source text's original function and to reproduce its effect on the new audience.

Semantic translation just explains the meaning of the original on the basis of the source language culture to help target-language recipients understand the discourse. Compared with literal translation, it pays more attention to the source language, context and the aesthetic value of the original, and it strives to keep the grammatical and syntactic features. In the translation practice, semantic translation and communicative translation both play its important role and will collaborate with each other.

\subsubsection{Hans Vermeer's Skopostheorie}

The skopostheorie gets its name from the Greek word "skopos" which means "purpose". It tries to liberate translation from the confinement of the source text. Skopostheorie was developed by Hans Vermeer in the late of $1970 \mathrm{~s}$. Later, he points out that one of the most important factors that decides the purpose of translation is the audience, the target language receptors. Thus, translation is the discourse produced by a certain purpose and its target audience in the target language conditions.

Vermeer (1984) puts forward three rules of translation: the skopos rule, coherence rule and fidelity rule. The priority is the skopos rule. In his opinion, the skopos rule is that human action (and its subcategory translation) is determined by its purposes (skopos), and therefore it is a function of its purpose. Coherence rule, the second rule, also named consistence in discourse, means that the version must be understood by the readers and meaningful in the target language and its communicative environment. And the third rule is fidelity rule named inter-textual consistence. It means that there should be coherence between the source text and the translated text. In other words, the translation is faithful to the original. These three rules are not separated from each other. Instead, they have a strong link.

\subsection{Research Methods}

Field investigation and case study are the main research methods of this study. Under the two methods, Gu Long Zhong in Xiangyang city and Three Kingdoms Red Cliff Ancient Battlefield in Chibi city are chosen as main research sites. And the English introductions to the two cultural spots and public signs there are mainly discussed.

\section{CLASSIFICATION OF PROBLEMS IN THREE KINGDOMS CULTURAL SCENIC SPOTS.}

\subsection{Overview of Translation of Scenic Spots}

Tourism translation serves for tourism activity, tourism major and tourism industry. The purpose of tourism translation is to give foreign tourists introductions to the spots or some instructions in the target language. It is all-inclusive, including scenic spots and historical sites, local conditions and customs, constructions, public signs and so on, which is decided by the feature of this industry.

Generally speaking, tourist resources can be divided into three categories. The first category is natural tourist resources, such as physiographic landscape, waters landscape, vegetation, and wide animal. The second one is 
humanistic tourist resources, such as historical sites, places of entertainment, festival celebrations. The third one is invisible tourist resources, such as, social system, ideology, lifestyle, education, etc. (Chen Gang, 2004).

Based on the above analysis, it is easy to find that tourist resources and tourism translation are all-embracing. Tourism translation includes all translation of the scenic spots, tourist activities. Obviously, the purpose of Chinese tourist materials is to build a bride for the cross-language communication, attract more foreign visitors, and advertise Chinese value and culture. It decides that the principle of tourism translation is regarding the spread of Chinese culture as the orientation and viewing the expected function of translation as the focus.

\subsection{Current Translation Situation of Three Kingdoms Cultural Scenic Spots in Jingchu area}

According to the tourism map of Jingchu area, it can be seen that the Three Kingdoms cultural scenic spots are concentrated in the Yangtze River stream line. In terms of prefecture-level cities in China, there are about 35 spots including Xiling Gorge, TigerPavilion and Huangling temple in Yichang city; there are Guan Ling, Huima slope, Zhou Cang tomb, Putra bridge, Madison site, Mi Cheng ruins, Changban slope and Yuquan Mt. in Dangyang city; there are Jingzhou ancient city, the Three Kingdoms park, Spring and Autumn pagodas, Huarong trail, Honghu scenic spot, Guandi Temple and Xiulin Mt. in Jingzhou city; Chibi ancient battlefield, Huanggai river, Lu Xun camps in Xianning city; Yellow Crane Tower, and worship altar in Wuhan city; the ruins of $\mathrm{Wu}$ Wang Cheng, west mountain spot, Xizhai mountain scenic area, Wunao mountain scenic area and Lingquan park in Ezhou city; Xiangyang ancient city and Gu Long Zhong in Xiangyang city. Among all translation of these spots, the translation situation is present in the following chart.

Chart 1: current translation situation

\begin{tabular}{|c|c|c|c|}
\hline & Translated & Omitted & Mistranslated \\
\hline Public Signs & $75 \%$ & $8 \%$ & $17 \%$ \\
\hline Brochure & $80 \%$ & $5 \%$ & $25 \%$ \\
\hline $\begin{array}{c}\text { Scenic Spot } \\
\text { Introduction }\end{array}$ & $65 \%$ & $10 \%$ & $12 \%$ \\
\hline Webpage Introduction & $70 \%$ & $18 \%$ & $16 \%$ \\
\hline Promotional Video & $63 \%$ & $26 \%$ & $20 \%$ \\
\hline Advertisement & $55 \%$ & $35 \%$ & $15 \%$ \\
\hline
\end{tabular}

Under the fieldwork and literature induction, the author chooses $\mathrm{Gu}$ Long Zhong in Xiangyang city and Three Kingdoms Red Cliff Ancient Battlefield in Chibi city as main research sites to do the case study. The English translation of the introductions to the two cultural spots and public signs there are mainly discussed.

\subsection{Classification of Problems}

By the collection and analysis of the data, it is found that those English versions are not satisfactory and there are various kinds of existingproblems. From the perspective of research, these translation problems can be categorized into two parts: the part of linguistic level and the part of cultural level. Besides, many other distinctive problems are also discussed.

\subsubsection{Linguistic Level}

Nord (2001) once stated that the differences in structure between two languages, especially in lexis and sentence structure, can cause some translation problems occurring in every translation that involves this pair of languages, no matter which of the two serves as source language and which serves as target language. According to this, followed are the problems seen from the linguistic 
approaches.

\section{(1) Vocabulary}

From this perspective, translation problems can also be divided into two aspects: mistakes in translation of proper name and mistakes in the choice of words. The author will use some examples to analyze one by one.

a) There are plenty of mistakes in translation of proper name. An appropriate name means the name of certain places.

Example (1):

$$
\text { 草庐 }
$$

Caolu

In the target language, “草庐” has the certain versions such as "hut" (referring to a small and crude shelter) or "thatched cottage" (referring to the craft of building a roof with dry vegetation such as straw, water reed, layering the vegetation so as to shed water away from the inner roof). But the version in the scenic spot just uses the Pinyin which may bring confusion to the foreigners.

Example (2):

隆中书院始建于五代天福年间, 被称为“武灵王学 业堂”。元代末年, 广德寺书院迁到隆中, 始称隆中书 院。

Longzhong Academy was built in Tianfu years of Yuan dynasty and was named as "Wu Ling Wang academic hall". At the end of Yuan dynast, GuangDesi academy was moved to Longzhong, and then it was called Longzhong academy.

In this example, “武灵王学业堂” is translated as “Wu Ling Wang academic hall” and “广德寺” is translated as "GuangDesi". Actually, when translating the name of places, it is the common practice that to combine the transliteration with literal translation. For example, "Mt. Lofty Ranges” should be translated as “罗夫迪岭山”. Thus, “武灵王学业堂” is supposed to be translated as “Hall of King Wuling” and the version of “广德寺” should be "Guangde Temple".

b) In some conditions, many English words alike, but they actually are very different. Even with the same Chinese meaning, there are still lots of detailed distinctions.

Example (3):

\section{元代末年}

At the end of Yuan dynast

This version mixes "dynast" with "dynasty". The two words look similar, but the meaning differs from each other. "Dynast" means a hereditary ruler, while "dynasty" refers to a series of rulers of a country who all belong to the same family or to a period of years during which members of a particular family rule a country.

\section{(2) Grammar}

English grammar is a series of systematic language principles after the targeted research on this language. And there are lots of grammar rules in English which can cause some mistakes when translating.

Example (4):

\section{桂花清可绝尘, 浓能远溢, 堪称一绝。}

The fragrance of osmanthus flowers is so refreshing that it make people forget about the material world and so thick that it spreads miles away.

English grammar requires that if the subject is singular, the predicate verb should be in singular form; if the subject is plural, the predicate verb should be plural. Thus, "it make people forget" should be corrected as "it makes people forget".

\section{(3) Syntactic Level}

After discussing C-E translation problems occurring in vocabulary and grammar, the author would turn to the syntax and analyze these various problems. Usually, short sentences and four-character phrases with more commas are used in written Chinese. In contrast, long sentences with less commas are used in written English. Besides, more conjunction words are applied in English to express the logic relation between those sentences.

Example (5):

桂花: 木犀科木犀属。常绿灌木或小乔木，园艺品 种繁多，最具代表性的有金桂、银桂、丹桂、月桂等。

Osmanthus: osmanthus family, osmanthus. Evergreen shrubs or small trees, there are various garden categories, typically including orange osmanthus, sliver osmanthus, 
osmanthusfragrans, laurusbobilla and etc.

The Chinese syntactical structure often reflects the feature of people's thinking way and the distinctive feature of parataxis. Thus the translators are supposed to grasps the general ideas, find out the logic relation and then reconstruct these sentences.

This version expresses the complete content of the original, but its structure may confuse the foreign tourists. “常绿灌木或小乔木” describes the nature of osmanthus in the original text, but the version connect it with the following words, which does not conform to the usage of English syntax and confusing in meaning. As a result, it may be translated like this:

"Osmanthus: osmanthus family, osmanthus, and evergreen shrubs or small trees. There are various garden categories, typically including orange osmanthus, sliver osmanthus, osmanthusfragrans, laurusbobilla and etc."

\subsubsection{Cultural Level}

The tourist spots, especially those with long history, are generally connected with its culture and these introductions must contain some cultural factors more or less. Those cultural factors may be a tough barrier for cross-language translators.

Example (6):

抱膝亭

Holding Knees Pavilion

“抱膝亭” is the place with a big stone on which, Zhuge Liang sat and sang the ditty "Songs of Father Liang" when living in Longzhong. And it is established to remind people of the situation that Zhuge Liang sang the song here holding his knees. But this version just uses the equivalent words in English. It cannot express the contained meaning and may bring difficulty to foreigners' understanding. Consequently, the correct version may be "Baoxi Pavilion".

Example (7):

\section{雷锋服务岗}

Lei Feng service post

In Chinese culture, when people mention Lei Feng, the spirit of selfless contribution must rise in mind. And this word is always used to refer to volunteer and service. But for foreigners, this version is not very clear and accurate. Maybe it can be translated as "Information\&Service" which is more acceptable for them.

\subsubsection{Other Problems}

\section{(1) Omission}

Example (8):

三顾堂是刘备三顾茅庐、诸葛亮作隆中对策的纪念 堂。该堂是清朝康熙五十八年 (公元 1719 年) 郧襄观 察使赵宏恩在原址上重建的四合院式建筑。其内之大殿, 诸葛亮与刘备隆中晤对的塑像栩栩如生, 连接大殿两侧 的回廊镶嵌着历代碑刻石碣。其外, 真立着三棵参天古 柏，相传此即刘关张三顾茅庐时栓马之柏。

Three Visits Hall was built to memorize Liu Bei's three visits to the thatched cottage (Zhuge Liang's house) and Zhuge Liang's Longzhong Strategy. It is a courtyard-style building reconstructed by Yunxiang Military Governor XhaoHong'en on its original location in Kangxi 58 years of Qing Dynasty (1719).

The original text introduces the usage and history of Three Visits Hall as well as its inner structure. But the version completely ignores the translation of inner structure which may leave foreign tourists with regrets and cannot introduce the scene comprehensively.

\section{(2) Chinglish}

Example (9):

\section{乃诸葛亮舌战群儒之所。}

Where Zhuge Liang verbal fight with scholars.

This version does not have a complete structure and there is not even a predicate verb in the version. It is greatly influenced by the Chinese language. Thus, the modified translation may be "It is a place where Zhuge Liang verbally fought with scholars.

\section{(3) Mistranslation of personal name}

Example (10):

\section{相传为诸葛亮设坛借东风之处。}

It is said that Zhugeliang had prayed for wind here. 
The three-character names in Chinese are generally translated in the way that the surname is separated while the characters of first name are put together. However, the translation of compound surname is different like 诸葛, 欧阳. Under this condition, the two characters of surname should be put together and the first name should be separated. Thus, “诸葛亮” is supposed to be translated as "Zhuge Liang".

\subsection{Influential Factors in Translation}

In this part, the author will analyze the major factors that influence the translation quality would be found out, such as cultural differences, translators and the type of the source text and purpose of translation.

\subsubsection{Culture Differences}

Culture is so important that it should be taken into account during the translation practice. It includes various aspects influencing the way a translator renders. And language is an indispensible part of culture. It is like a mirror reflecting the national historic tradition, values, mind of thinking and social mentality, a window to reveal all contents of the culture and a bridge to spread and pass down culture to the next generation. As a cross-cultural communicative activity, its content is not only the phonetic symbols but also the culture behind them.

Firstly, lexical ambiguity caused by cultural differences will affect the version in a sort of way. Vocabulary is the basic structure of language and the backbone supporting the whole language system. Thus, the effect of cultural differences is the most deeply shown in vocabulary, whose sphere of influence is the widest. Because Chinese and English respectively belong to different cultures and language family: the former belongs to the Sino-Tibetan Family while the latter is part of Indo-European Family, there is little expression that can be directly conforms to each other. Most expressions between the two languages are different on conceptual meaning or cultural meaning. If the translator do not pay much attention to them and just assumes translation as a matter of course, one false step will make a great difference.

Secondly, the lack of background knowledge is the biggest barrier for translation because the possession of knowledge is the premise of translation. Both Chinese and
English have a long history and in the course of their nations' development, they are enriched by some vivid expressions according to the national style and regional characters. Those languages only represent the special matters and phenomenon. Every text is written with background knowledge and the translator should understand the history, literary quotations and terms involved in the text in order to reduce or even eliminate the negative influences of the cultural differences. For example, the chronology in ancient China is unique and it cannot be well understood by foreigners. In $\mathrm{Gu}$ Long Zhong, “康熙五十八年” can be translated as “the fifty-eight year of the region of Emperor Kangxi”. This version can better explain the identity of Kangxi and the meaning of “五十八年”.

Thirdly, the ways of thinking can obstruct the cross-cultural translation. Every nation has its own historical accumulation and solid structure of the national psychology. And every person is bound to have the psychogenetic genes of his or her own country, nation as well as region. These genes determine his or her spiritual temperament, way of thinking, behavior and so on. Based on that, features in different nations and regions are formed which can greatly affect the accuracy of translation. There are lots of set structures, idioms and locutions in English differing from Chinese. Whether a translator can correctly deal with those expressions with different cultural psychology is the key to render. For example, “破 天荒” means the unprecedented and surprising thing. And how to translate it properly is a challenge for translators.

\subsubsection{Type of the Source Text}

In terms of foreign scholars, Reiss (1987), the forerunner of modern functional theory, connected the textual types, with its functions as well as translation methods and came up with three text functions: informative one, expressive one and inducible one. Based on Reiss' theory, Newmark (1981) launched his own theory about text classification. He classified the text variety into vocative text, informative text and expressive text. Furthermore, the key to expressive text is the idea of authors which is indispensable. Besides, informative text focuses on the outer situation and the fact of some matter. As for the vocative text, its core is audience, and what is 
important is not the identity of author but the effects of information transmission and feelings of target readers. In other words, vocative text attaches high importance to the reader effect. As for Chinese scholars,JiaWenbo, an esteemed Chinese translator and scholar, refers to tourist information as vocative text. "Tourist translation should focus on the equivalence of informative and problem functions between the original and the version. The equivalence of the form is not its core and tourist translation is not a platform presenting the linguistic and cultural heterogeneity. It is like advertisement, whose purpose is to attract tourists and achieve the expected effect of related products.'(JiaWenbo, 2004:20) But beside the vocative function, tourist text should have informative and expressive function. Just like what Wang Baorong (2005) once said that foreign tourists come from afar and what attracts them most is not only the landscape and pavilions, but also the culture behind that. Consequently, translation of tourist information should pay attention to the cultural factors.

\subsubsection{Translation Purpose}

According to Vermeer's skopostheorie, translation is not viewed as a process of transcoding and every kind of translation would target some audience. Thus, translation should be made to fulfill the target text purpose in the target text situation. Translation purpose can be defined as the desired effect or change that can help the target society reach a kind of desired objective state. Translation purpose can be decided by the initiator, client, or the translator himself.

In The Purposiveness of Selections in Translation, Fan Xiangtao and Liu Quanfu (2002) came up with the multi-level translational purpose. They state that each translation action and the selections involved are regulated or directed by purposes at different levels. By analyzing, they classify the purposes into three levels. First is the ultimate goal of a translation activity, such as cultivating talents for the development of science. The next one is the purpose of provisional stage, such as to provide a reference book for teachers. And the last level is the basic purpose, such as to develop the publishing house so as to make it more competitive. Depending on the descriptions of these skopos, he launches three distinctive principles for his category: the overall desired effect on the target society, the intentions of the initiator or the translator, and the benefit brought on the translator himself through the version. For example, as for the intentions of the translator, when rendering the “雷锋服务岗”, if translator wants to present the culture contained in the original, the version will be "Lei Feng service post". If translators are aimed at giving foreigners earlier understanding, it can be translated as "Information \&Service".

\subsubsection{Translator's Interpretation}

Some people say that translators are servants for two masters: the reader and the author. As is known to all, comprehension and expression are two essential ingredients of translating. First, the correct understanding of the original work plays an essential role in the whole process. That's why, at the very beginning, translators should not hurry to do our translation, instead, they are supposed to read the whole passage patiently to make sure that the general idea is correctly comprehended. Moreover, a translator's expression is supposed to be accurate, flexible and impressive and his language is hoped to be vivid, with its form beautiful.

Translation is an arduous work that requires lots of efforts of a translator due to the special linguistic features and cultural differences between Chinese and English. Most translators are familiar with many translation strategies and methods, but they could still make some mistakes if facing a certain cultural words and expressions. As a result, professional translators are supposed to equip the following qualities. Firstly, they should acquire skills and experiences in analyzing both of the languages and get to be aware of the cultural differences between the languages. Secondly, being able to write smoothly in both source and target languages is also important. Writing is in fact the main job of a translator. Thirdly, professional translators should be highly specialized, that means, translators should have specialized competence in a particular area. And translators have to work very hard for many years with relentless efforts and a rigorous attitude. Take “关羽败走麦城” as an example. The translator with poor ability may translate it as "Guan Yu lost the war and escaped to Mai Cheng". However, there is a phrase "to meet one's Waterloo" which means that who has been 
defeated badly. Professor Tian Chuanmao (2010) with better cross-cultural awareness and ability of expression translated it as "Guan Yu met his Waterloo". The latter version is more readable to foreign tourists.

\section{TRANSLATION STRATEGIES}

After researching prose structures of tourism translation, our researchers have found that in Chinese culture, introductions to beautiful scenery and courts prefer the usage of words and phrases. Particularly, they refer to history as the background and make use of four-character phrases to present the affluent connotation of the scenic spots. In terms of structure, Chinese writing pays high attention to the rhyme and oral style. However, in western countries, the principle of writing about scenic spots is to use simple words and to focus on description without too many adjectives.

Based on Vermeer's skopos theory and Peter Newmark's (1981) communicative translation, the author would like to present some translation strategies and techniques, which may help translators address the errors of the same nature.

\subsection{Strategies under Communicative Translation}

Communicative translation attempts to produce on its readers an effect as close as possible to that obtained on the readers of the original. As a result, domestication and foreignization can be chosen.

Foreignization is a source-language-oriented translation. It can make readers experience the culture from the translated works because in this translating way, readers are guided by the translators to the author, which can preserve the style of the original text, even the order of sentences. But domestication is a kind of target-language-oriented translation. It asks translators to change the expression of source text in order that the author can move to the reader. For example, “运筹帷幄, 决胜千里之外” is translated as “mapping out a strategy in the tent, and winning the victory a thousand miles away". This version uses domestication and it explains the general meaning of the original.

In tourism translation, both of the two strategies can achieve the purpose of translation and each of them has its own advantages. On one hand, foreignization can keep the uniqueness of Chinese tourism culture and attract potential foreign tourists. But if there is too much cultural information contained in the original text, this strategy will make the version difficult to understand and foreigners cannot have a great travel experience. By contrast, target-language readers can easily to understand the translated works in the way of domestication because these versions are closer to their language habits. However, domestication gives more attention to the style and expression of target language which will ignore the features of our culture. It may lead to the dislocation of Chinese unique tourism culture. Thus, translators should combine them when translating material in scenic spots.

\subsection{Strategies under Skopos Theory}

There are three principles in the Vermeer's skopos theory: skopos rule, coherence rule and fidelity rule. Under these rules, some techniques can be advocated in translation of scenic spots.

\subsubsection{Under the Skopos Rule}

Skopos rule is the most important one in skopos theory. It means that translation should be made to fulfill the target text purpose under the target text situation. In other words, to achieve the expectation, version cannot be equivalent to the original. Under this rule, translators can use translation techniques like negation and omission.

Negation is the method that the original text is written in one angle while the version is made in another angle. Due to the different thinking modes between the Chinese and English, their expressions are not the same. To make the version more acceptable to target readers, negation should be used when translating. And it can be applied in the translation of words, phrases and sentences. For example, in many Three Kingdoms cultural scenic spots, the public sign “游客止步” is translated as “Staff Only” and the version of “请勿践踏草坪” is “Keep off the Grass”. And the sentence “此票逾期无效” is translated as "The ticket is valid in the specific date and time" which is more acceptable to foreign tourists.

Omission is a technique opposite to amplification. It is true that a translator has no right to subtract any 
meaning from the source text. However, it does not mean that translators should be prevented from omitting any words at all in translation. What is regarded as a natural or indispensable element in one language may be regarded as superfluous or even "a stumbling block" in the other. For example, the version of “水深危险, 注意安全” is “Beware of deep water". Besides, some signs designed for domestic tourists need not translation such as “学生证半价” and “老年人凭证免票”, because these sentences will not influence the travel of foreign visitors.

\subsubsection{Under the Coherence Rule}

With the guide of coherence rule, imitation is a better choice for the translation in Three Kingdoms cultural spots. It means translating according to the syntactic structure of known information which is fixed and standardized.

With the boom of tourist industry, our government increasingly attaches more importance to tourism translation. In 2006, "English Translation of Bilingual Signs in Public Places" was launched which contained versions in various sectors like scenic spots, transportation, business services and so on. Later, "Standards for English Translation and Writing in Public Service Areas" at the national standard was enforced officially on Dec. $1^{\text {st }}, 2017$. It specified the four translation principles of public service areas and three strategies of public signs of tourist attractions. Thus, translation in these scenic spots can refer to the standardized sentence pattern and format. For example, forbidden signs should be translated as "Don't..." , "No..." or "... Forbidden" such as "No Smking". Warning signs is usually rendered with imperative sentence like "Caution! Wet floor". What's more, some English locutions can be borrowed. For example, the sentence "talk of the evil and he appears" can be used to render “说曹操, 曹操到” and “meet one's Waterloo" for “败走”.

\subsubsection{Under the Fidelity Rule}

Fidelity rule means information transformation and functional expression of the version should be the same as that of the original. That is to say, version must keep fidelity to the original text. As a result, translators can choose literal translation. Literal translation means that the version is supposed to be faithful to the context of the original work and to be in the tune with its linguistic and stylistic structure.

But in reality, translators usually combine literal translation with free translation, especially in tourism translation, or the version may be a mass. Free translation means that the translator should focus on the profound meaning of the original without too much attention to details. But free translation also requires fluent and expressive version. Also take “雷锋服务岗” as an example, it should be translated as "Information \&Service" instead of “Lei Feng service post”. And “赤兔马” is the horse of Cao Cao. It can be translated as "Red-hare Horse" that can give receptors the same feeling as that produced on the original readers.

\subsection{Enlightenment for Cultural Communication}

Language is not just a communicative tool for mutual understanding, but a real world, the spiritual home established during the process of people's comprehension to the objective world. Like the language, culture is also an open system which has inclusive freedom and possible recombination. Since the reform and opening up, the Chinese society has been increasingly inclusive and there have been more opportunities for foreigners to touch Chinese culture. And better versions and prosperity of Three Kingdoms Culture must be the driving force for cultural communication.

Nowadays, English speakers are still the largest group of language speakers. Thus, it is of great importance to translate the sentences and passages with Chinese characteristics as well as possible. However, the language habits, discourse system and expression of thinking between Chinese and English are totally different. From the perspective of culture communication and exchanges, problems of public opinion guidance and culture protection are obvious. As a result, translation strategies play an essential role when translating. They are not just the language conversion skills because languages all have vitality which is rooted in special cultural soil. Only with flexibility, can translation be meaningful.

\section{CONCLUSION}

This research adopts literature induction and field 
investigation to research the current translation situation in Three Kingdoms cultural spots, especially in $\mathrm{Gu}$ Long Zhong and Three Kingdoms Red Cliff Ancient Battlefield.With complete investigation and coordination of the current translation situation, major translation problems are discussed as well as influential factors. What's more, some translation strategies are given for reference to modify the versions.

\section{DECLARATION OF CONFLICTING INTEREST}

The author declares that there is no conflict of interest.

\section{FUNDING}

This work was supported by the Hubei Provincial Department of Education, P.R.China [Grant No.: 19ZD021; and Grant No.:18Y056]; the Institute of Science and Technology Development, Yangtze University, P.R.China [Grant No.:2018csz07]; and the Advantageous and Characteristic Humanities of "Modern Education and Jingchu Culture Research", Yangtze University [Grant No.: 2018YYY10]

\section{REFERENCES}

[1] Christiane Nord. Translating As a Purposeful Activity-Functionalist Approaches Explained [M] Shanghai: Shanghai Foreign Language Education Press, 2001.

[2] Reiss, K. Text Type, Translation Types and Translation Assessment [A] In Chesteman, A (ed.). Readings in Translation Theory[C].Heisinki: Finniectura,1987.

[3] Newmark, Peter. Approaches to Translation [M]. Oxford:Pergamon Press, 1981.

[4] Newmark, Peter. A Textbook of Translation [M]. Shanghai: Shanghai Foreign Language Education Press, 2001.

[5] Shuttleworth, Mark and Moria Cowie. Dictionary of Translation Studies [M].Manchester St. Jerome Publishing, 1997

[6] Vermeer, Hans. J. The Framework of General Translation Theory [C]. Berlin: Verlag, 1978.

[7] Vermeer, Hans. J \& Reiss. General Foundation of Translation Theory [M].Tubingen: Niemeyer, 1984.
[8] Chen Gang. Tourism translation and foreign tour guide [M]. Beijing: China International Translation and publishing company, 2004.

[9] [9] Fan Xiangtao, Liu Quanfu. On the purposefulness of translation choice [J]. Chinese translation, 2002 (06): 27-30.

[10] [10] JiaWenbo. Functional theory of Applied Translation [M]. Beijing: China translation and publishing company, 2004.

[11] [11] Wang Baorong. English translation of tourism culture: Domestication and Foreignization: a case study of Shaoxing's famous scenic spots [J]. China Science and technology translation, 2005 (01): 13-17 